\title{
Frankfurt Goes Kantian - But How Does It Work?
}

\author{
Marcus Düwell
}

\section{Introduction}

Rainer Forst gives discourse theory a turn in which the Kantian heritage is more strongly emphasized than with earlier authors of the so-called Frankfurt School, such as Adorno, Habermas or Honneth. Adorno's relationship to Kant has always been ambivalent. On the one hand, he criticized Kant quite superficially for being un-historical, bourgeois or un-dialectical. On the other hand, there are numerous alliances between both authors on a deeper level. Thus, it will be difficult to make sense of Adorno's criticisms of modern societies in Minima Moralia ${ }^{1}$ without some concept of morality in the Kantian tradition. Or Adorno's ambivalent take on history: on the one hand his writings seem to be driven by the conviction of the Dialectic of Enlightenment that history fails right from the beginning - which seems to presuppose metaphysical knowledge about the course of history. On the other hand, we find views about Utopia and reconciliation - particular in the Aesthetic Theory ${ }^{2}$ - where Adorno embodies an attitude regarding history which is more methodologically aligned with the Kantian critical project than with Hegelian knowledge about history.

While uncovering Kantianism in Adorno requires some detective work, Apel and Habermas have always admitted their Kantian heritage frankly. However, they emphasized the necessity of transformation of classical philosophy, ${ }^{3}$ since the role of the subject would have to be reconsidered after the so-called 'linguistic turn.' The Frankfurt mantra since that time has been: if we have to see the subject as a result of structures of meaning that are developed in language (that means on a supra-individual level), then neither epistemic reliability nor the validity of our moral convictions could be justified in the subject, but must find its justification in relational, dialogical or intersubjective structures. For the 'transformation' of ethics and political philosophy this has various consequences: firstly, for Kant moral justification is self-reflexive in the sense that human beings have to ask themselves what kind of beliefs or judgments they should necessarily endorse. For Kant, moral justification does not aim to find a subject-independent truth, but the critical project (the transcendental justification) aims to identify convic-

1 Theodor W. Adorno, Minima Moralia. Reflections From Damaged Life. Trans. E.F.N. Jephcott (New York: Verso Books 2006, originally Frankfurt am Main: Suhrkamp-Verlag, 1951).

2 Theodor W. Adorno, Aesthetic Theory. Ed. Gretel Adorno and Rolf Tiedemann. Trans. Christian Lenhardt. (London and Boston: Routledge and Kegan Paul, 1984, originally Frankfurt am Main: Suhrkamp-Verlag 1970).

3 Karl-Otto Apel, Towards a Transformation of Philosophy (Milwaukee: Marquette University Press, 1980). 
tions that the subject must hold in order to avoid rational self-contradiction. For Apel and Habermas, the (quasi-)transcendental justification cannot take the subject as its starting point, rather the discourse community would be the reference point of their considerations. Secondly, for Kant the procedure of universalization starts with the maxims an individual may have and asks whether or not these maxims could function as universal laws. Apel and Habermas do not start with individuals' maxims, but ask what kind of discursive procedures about norms of actions can be universally accepted. Thirdly, for Kant the connection between the procedure of universalization and the idea of respect for rational beings is of central importance. As rational, practical beings we are capable of applying practical rationality to ourselves; we can wonder what kind of means we must choose to achieve specific goals, we can wonder what kind of ends we want to realize and we can ask ourselves what kind of maxims all practical beings must endorse. As beings with this capacity, we deserve to be respected by all rational beings, as Kant emphasizes with the 'Formula of Humanity.' The social construction that follows from this - the 'kingdom of ends' - requires subjects to treat each other as 'ends in themselves,' but it does so because each member of this kingdom has to understand himself or herself as such an end worthy of respect. In the Frankfurt fashion, this would have to be questioned: if the transcendental argument does not refer to the subject, the idea of respect for rational nature cannot be justified in the same way. That is the reason why discourse ethics primarily offers a procedural approach. Accordingly, 'human dignity' did not play a significant role in most of Habermas's oeuvre. It was only in the late 1990s, when he considered bioethical topics, that he referred to some idea of human dignity, ${ }^{4}$ and later on he tried to develop human dignity as a foundational concept. ${ }^{5}$

Against this background, Rainer Forst's commitment to a Kantian framework is not self-evident. As a Kantian, I'm sympathetic to his argumentation to a great extent. I can understand the idea that a historical explanation of the development of human rights and their transcendental justification do not have to be mutually exclusive. I can follow the way he introduces the concept of human dignity. And I am with him when he criticizes Habermas for the way in which the relationship between (human) rights and democracy is conceptualized, and when he highlights the lack of moral justification of democracy and law in Habermas's framework. In all these regards, I agree that his paper shows the right direction. However, there is a variety of aspects where I do not understand how Forst's approach can work, and how it can be compatible with the basic assumptions of discourse theory.

4 Jürgen Habermas, The Future of Human Nature, trans. Hella Beister and Willima Regh (Cambridge: Polity Press, 2003).

5 Jürgen Habermas, 'Human Dignity and the Realistic Utopia of Human Rights,' Metaphilosophy 41, no. 4 (2010): 464-80. 
To say 'I do not understand' is meant quite literally, and I would like to understand it because it has to do with my own project. ${ }^{6}$ I will explain below how I understand the Kantian project, which is inspired by some methodical comparisons between Kant and the work of Alan Gewirth. ${ }^{7}$ Basically, I assume that we must get some understanding of our own moral status as agents from the firstperson perspective. I assume that it is crucial for a concept of human dignity that we can understand the normative importance of persons from this perspective. I assume that I cannot consistently understand myself as a rational being if I do not assume that I am worthy of respect and at the same time I have this in common with everybody else. Therefore, we must treat each other with respect and must form a political community that embodies this respect. I wonder whether Forst can reach his conclusions without sharing this basic assumption, and accordingly how the relationship between the approach of Kant and Forst can be understood. Therefore, I am grateful for the opportunity to discuss this with Rainer Forst.

The remainder of the paper will articulate these questions. I will (Section 2) discuss the relationship between discourse theory and transcendental argumentation when it comes to the role of the subject, (Section 3) discuss how we can determine the content of rights and the scope of the right-holders, and (Section 4) conclude with some final remarks.

\section{Transcendental argument and discourse theory}

Rainer Forst makes explicit that the normative foundation of his argument is the status of the person as commanding respect. This requires that we have to respect the normative authority of persons, we have to treat them equally and as free human beings. He calls this the 'right to justification.' In a basic sense, this right forms the basis of a moral relationship that implies (in a non-instrumental sense) the basic right to co-determine the structure of one's society.' Basic rights are also 'rights to determine the rights and duties that define' 'one's status as a legally, politically and socially non-dominated person. ${ }^{8}$ The theory is based on a moral concept of the dignity of the human person, and this moral basis translates into political obligations to organize the normative social and political order such that human beings are not denied the status of a normative authority, which cannot be justified to them as free and equal persons. On this moral ground, Forst says:

6 Marcus Düwell, 'Human Dignity: Concept, Discussions, Philosophical Perspectives,' in Cambridge Handbook on Human Dignity, ed. Marcus Düwell et al. (Cambridge: Cambridge University Press, 2014), 23-49; Marcus Düwell, 'Transcendental Arguments and Practical Self-Understanding - Gewirthian Perspectives' in Transcendental Arguments in Moral Philosophy, ed. Jens Peter Brune et al. (Berlin: De Gruyter, 2017 forthcoming), 161-77.

7 Alan Gewirth, Reason and Morality (Chicago: University of Chicago Press, 1978).

8 Rainer Forst, 'The Justification of Basic Rights. A discourse-theorethical approach', Netherlands Journal of Legal Philosophy 45(3), 8. 
'It is important to understand that these rights, even though they aim at a legal, political and social status and can only be justifiably fully determined and realized in a democratic regime, have a "ground" that is both moral and, if you will, transcendental: the autonomy of persons with a right to justification as a normative authority equal to all others. ${ }^{9}$

Forst sees this approach as Kantian insofar as it is based on the moral authority of the person. He sees it at the same time as an approach belonging to the tradition of discourse theory insofar as the content of the rights and duties must be approved by the discourse partners.

Thus far, I do not see how the underlying transcendental argument really works. I must confess that I have this problem not only in the current paper but also in Forst's earlier texts in the collection The Right to Justification. ${ }^{10}$ I will first focus on the general structure of the argumentation itself and in the next Section I will come to the question of what this would mean for the determination of the content of rights.

Forst emphasizes that his concept is 'deontological' and starts from a Kantian concept of a person, therefore it does neither depend upon a concept of values nor does it embrace an interest theory of rights. Rights are not based on values and rights are not protecting access to values. Likewise, human interests are not the normative foundation of rights; we do not have rights to specific goods because we have some basic interests in them. Rather, the autonomy of persons is the reason why we have 'normative authority equal to all others.' An autonomous person has the basic right only to be subject to an order in which he is a coauthor, and therefore a democratic procedure must be in place in which he has an equal standing in the creation of this normative order. At the transcendental level, the central argument is that 'autonomous persons deserve respect as normative authorities.' From this moral starting point, normative consequences must be drawn regarding the appropriate forms of procedures for determining the rights that govern political life. In this regard, the consequences are procedural rather than material. But, of course, each procedural approach makes some material assumptions. The basic assumption is that autonomous persons deserve equal standing in the creation of a normative order. And this basic assumption is the ground for rights. Human dignity is understood as this basic equal standing of autonomous persons, the 'right to justification' is only another way of framing it. The equal moral standing of autonomous persons would be ignored if our right to justification of those norms to which we are subject would not be respected. I hope this is an appropriate reconstruction of Forst's argument. But then the question is what kind of transcendental argument could provide a justification for Forst's claims? The argument must be one that ascribes moral status to individual persons which requires respect from all others. This respect for the person forms

9 Forst, 'The Justification of Basic Rights', 10.

10 Rainer Forst, The Right to Justification, trans. Jeffrey Flynn (New York: Columbia University Press, 2011). 
the moral basis for the claims to co-authorship of the political order. The question is now, in what way can this approach be transcendentally justified?

Let us for a moment reflect on what transcendental justification in general can mean. There are substantial debates about the question of what we could mean by transcendental justification, in contemporary philosophy as well as from a historical perspective. These debates are not always centred on the same topics. In some sense these debates go back to the ancient criticism of the sceptic doubt of the existence of the outside world, and the general possibility of human beings attaining certain knowledge. The basic structure of such an argument by most authors considered as follows: in questioning whether a certain claim $\mathrm{X}$ is valid, the proponent of $\mathrm{X}$ can argue that $\mathrm{X}$ is a necessary condition of another claim $\mathrm{Y}$ that the sceptic cannot deny for some reason $\mathrm{Z}$, either because he (implicitly or explicitly) already accepted $\mathrm{Y}$ or because $\mathrm{Y}$ cannot be denied as such. Transcendental arguments are in this sense not directly arguing that certain claims are true, they rather show that someone must be committed to some convictions due to the fact that he is committed to other convictions that he cannot rationally hold if he denies those convictions. An example would be the Cretan who claims that all Cretans are liars, which he cannot hold because by making these claims he must hold the conviction that at least his own statement is not a lie, otherwise he would undermine the validity of his own claim. Transcendental arguments have therefore a self-reflexive or 'retorsive' structure. ${ }^{11}$

In modern times, Descartes' attempt to anchor this knowledge in the self-relationship of the Ego cogito is a relevant point of departure. In the 20th century, Peter Strawson has attempted to provide a transcendental answer to metaphysical and epistemological problems. ${ }^{12}$ This, and similar attempts, have been the subjects of various critical debate ${ }^{13}$ whether or not transcendental argument can really give us epistemological certainty and what the costs for this certainty would be; if this certainty comes at the price of transcendental idealism (that all our convictions about the metaphysical questions concerning the objectivity of the outside world would ultimately rest on human ideas), various authors doubt whether they would be willing to pay this price.

Alongside these attempts to refer to transcendental arguments in 'theoretical philosophy' to provide answers to questions such as 'Can we be certain about the existence of the outside world?,' there is a practical line of transcendental argumentation. This line goes back to Kant, and deals with the question of whether or not we can find a transcendental justification for moral commitments and - since those commitments are necessarily bound to human freedom - to the question whether or not we must understand ourselves as free. Even so, whilst there may

11 Christian Illies, The Grounds of Ethical Judgement. New Transcendental Arguments in Moral Philosophy (Oxford: Oxford University Press, 2003).

12 P.F. Strawson, Individuals (London: Methuen, 1959).

13 Barry Stroud, 'Transcendental Arguments,' Journal of Philosophy 65 (1968): 241-58; Robert Stern, Transcendental Arguments and Scepticism: Answering the Question of Justification (Oxford: Oxford University Press, 2000). 
be fundamental similarities between the two uses of transcendental arguments, there are also some differences. Theoretical transcendental arguments about the existence of the outside world and practical transcendental arguments do not necessarily have to face the same challenge. It may be that for human freedom and the respective moral commitments it is sufficient if we can show that we must see ourselves as free and morally committed to the moral law out of rational necessity, and the question arises as to whether it is necessary to prove whether we are 'really' free.

This practical argument has been explicitly discussed in Kantian moral philosophy. The difference between the contemporary and the Kantian discourse is that, for example, Peter Strawson (and his critics with him) assumes that the transcendental argument is one that must work on the basis of the semantic content of concepts. This implies that the semantic of a concept like 'person' or 'agency' would force us to embrace some other concepts like 'moral law.' The practical transcendental argument along these lines would work in the following way: if we have the concept of an 'autonomous person,' we also have the concept of a moral law to respect the autonomy of persons. The suspicion is that this works as a sleight of hand where the moral rabbit is pulled out of the conceptual hat. How the Kantian argument works is nowadays matter of some discussions. In my reading, one can only make sense of the Kantian argument if one assumes that Kant does not work on the semantic basis. Kant rather starts with a human being who forms judgments, and tries to understand what is presupposed by being able to form judgments. The starting point for Kant is the judging being, a being who forms judgments about facts in the world, about moral commitments, about the beauty of aesthetic objects, and so on. The central Kantian question is then what is required for the 'capacity to judge.' This capacity cannot be circumvented, because each criticism of this capacity must come in form of a judgment, it presupposes already that we are capable of judging. A variety of contemporary authors have put the 'capacity to judge' at the centre of their interpretations of Kant. ${ }^{14}$ Such an approach is not necessarily committed to transcendental idealism, in the sense of necessarily relying on the metaphysical assumption that the outside world is only a human construction. The judgment-approach to Kant is rather based on the assumption that before those metaphysical and epistemological questions can be asked, we must gain an understanding of the 'capacity to judge,' because this capacity is a prerequisite to asking those questions.

What does this mean for Kantian practical philosophy? It is claimed in the older literature that Kant failed to provide a transcendental proof of our freedom and

14 See for example David Bell, 'The Art of Judgment,' Mind 96, no. 382 (1987): 221-44; D.K. Düring and M. Düwell, 'Towards a Kantian Theory of Judgment: The Power of Judgment in Its Practical and Aesthetic Employment,' Ethical Theory and Moral Practice 18, no. 3 (2015): 943-56; Beatrice Longuenesse, Kant and the Capacity to Judge (Princeton: Princeton University Press, 1998); Rudolf Makkreel, Orientation and Judgment in Hermeneutics (Chicago: Chicago University Press, 2015); Klaus Steigleder, Kants Moralphilosophie; die Selbstbezüglichkeit reiner praktischer Vernunft (Stuttgart: Metzler, 2003); Wayne Waxman, Kant's Anatomy of the Intelligent Mind (Oxford: Oxford University Press, 2014). 
related to an argument for the transcendental necessity of the moral law, which is premised on the existence of freedom. A variety of contemporary authors have interposed that this criticism assumes that Kant aims at a theoretical proof of freedom, a proof that we would really 'be' free, while Kant always insists that such a theoretical proof is impossible, and that this is not what he is aiming for. He rather aims at a practical proof, which means he aims at reconstructing a set of beliefs that a practical being would have to hold from his first-person perspective, and he furthermore aims to show that persons would have to uphold these convictions not contingently but that it is necessary for them to hold those beliefs, otherwise they would not be able to consistently understand themselves. ${ }^{15}$ That means that Kant would not show that human beings 'are' free, but that they can do no other than understand themselves as free and that this freedom comes with the ability to set goals of action and at the same time entails a commitment to the moral law as elaborated in the categorical imperative.

I explained this in some length because I want to understand how Forst's claims relate to this view on Kant. Apel's transcendental argument would be that the human beings must be committed to specific norms because those norms are preconditions for the possibility of discourse, and as participants in the discourse human beings cannot rationally avoid those commitments. Habermas subscribes to this idea with some modifications, in the sense that he only sees the commitment as unavoidable from a pragmatic perspective but he does not assume a strong transcendental argument to be possible, he speaks about a 'quasi-transcendental' argument. Independently of those details, along this line of thought the idea is not that the 'respect for the autonomous person'/human dignity has a foundational role to play. It is rather the idea that the (quasi-)transcendental argument identifies the conditions under which rational deliberation is possible in the first place and the moral norms and principles, including the respect for persons, must be agreed upon within this deliberation. ${ }^{16}$

The question is now, where Rainer Forst should be placed within the spectrum of these alternatives. If 'respect for the autonomous person' is the basis for the 'right to justification,' then the question is basically whether this should be inter-

15 See for example Pauline Kleingeld, 'Moral Consciousness and the "Fact of Reason",' in Kant's Critique of Practical Reason. A Critical Guide, ed. Andrews Reath and Jens Timmermann (Cambridge: Cambridge University Press 2010), 55-72; Steigleder, Kants Moralphilosophie; Onora O’Neill, 'Autonomy and the Fact of Reason in the Kritik der praktischen Vernunft (§§ 7-8, 30-41),' in Kritik der praktischen Vernunft. Klassiker Auslagen Bd. 26, ed. Otfried Höffe (Berlin: Akademie Verlag, 2002), 81-98; Michael Wolff, 'Warum das Faktum der Vernunft ein Faktum ist. Auflösung einiger Verständnisschwierigkeiten in Kants Grundlegung der Moral,' Deutsche Zeitschrift für Philosophie 57, no. 4 (2009): 511-49.

16 One should mention that there is a possibility for a slightly different reading, in Apel's earliest version of the argument (German 1973, Engl. 1980). Apel flirts with the idea that the conditions of rational discourse form rights and that the respect for a person would be the material content of the morality of discourse, since one could say that the recognition of a person as a discourse partner materially coincides with the respect for a person. In later writings, however, Apel explicitly rejects this interpretation. See in this context Gerard Schönrich, Bei Gelegenheit Diskurs - Von den Grenzen der Diskursethik und dem Preis der Letztbegründung (Frankfurt: Suhrkamp, 1993). 
preted in the Apel-Habermas line or in the Kantian line as I sketched it above. Or does Forst work on another interpretation of the Kantian project? In that case I would like to learn what the Forstian reconstruction of Kant's transcendental argument is. In any case, I guess that here is a real philosophical alternative. If one wants to provide a transcendental argument for the human dignity/respect for autonomous persons as the basis of a normative order, I fail to see what such an argument can look like without referring to the rational self-understanding of those persons themselves. The transcendental justification must be embedded in the convictions that the agents must hold about themselves. Such an argument will not necessarily be solipsistic in the sense of the agent being uncertain about the existence of the outside world and about the existence of other minds. But in any case, the specific status of a person that deserves respect must be part of the rational self-understanding of those agents. We must respect each other because we have to see the other in the same way as an autonomous person, and to assume that this commitment to rational personhood is relevant in the same way for their rational self-understanding. In that sense such a Kantian strategy is not monological, but it shows why we have reasons to respect the other because of the general dignity of rational persons. This consideration cannot be formulated within a framework of Apel and Habermas. This also means that Forst cannot rely on their transcendental justification and I guess he should join the Kantian camp in the line of the argument I outlined above.

\section{Which rights? Whose rights?}

A second cluster of questions is related to the determination of the content of rights and the scope of rights-holders. Concerning the content of the rights, Forst claims that in a normative order based on the dignity of the autonomous person, the citizens should themselves determine which rights and duties should govern this order. The reason is that otherwise the autonomy of the citizens would not be respected. It is only if the citizens are the co-authors of the normative order that they are treated with the respect that an autonomous person deserves. I can understand that, and fully agree with, the idea that it is imperative for a normative order on the basis of human dignity to ensure the effective power of citizens to the shape the constitutional order and political life. But I cannot understand why we are not able to formulate criteria to measure whether or not a legal order seriously fulfils the normative requirements that a dignity-based order should govern. I am not thinking here of a kind of checklist for valid constitutions, but rather about considerations that enables us to specify requirements that must be fulfilled for a normative order on the basis of human dignity. I cannot, for example, see how one could respect autonomous persons without protecting some conditions that those persons need in order to function autonomously. Some biological and ecological conditions, for example, are necessary to enable human beings to realize their autonomy in a very fundamental way. How could an order be acceptable with respect to Forst's own normative standards if such an order endangers those conditions? And does such a normative order not necessarily 
require there to be institutional arrangements that ensure that citizens have the security required for political participation, and equally the opportunity to form their own opinions about political matters that are necessary for such participation? This does not mean that the entire argument need be transformed into an interest-based approach. I agree with Forst that a Kantian approach cannot be interest-based in the sense that having interests as such forms the normative grounds of rights. But if respect for autonomous persons is the fundamental normative basis, this will not only justify procedural normative considerations but would directly result in the requirement to protect those conditions that are necessary to exercise this autonomy. And since for human beings some biological and social conditions are required to exercise this autonomy, the denial of access to those conditions would be a violation of the respect that - according to Forst forms the normative basis of his approach. Of course, we can dispute what these conditions are and there must be room for reasonable disagreement. It is therefore necessary to install procedures that ensure that a discourse about those conditions themselves is possible, and that citizens have the right to determine this order themselves. But I fail to see why there are not content-related criteria by which we are able to assess whether the outcome of these procedures conforms to the requirements of respect for human dignity.

This may sound like quite an academic debate, but it also has some practical dimensions. First of all, if the people should determine the content of human rights themselves, those that have less (economic, intellectual, social etc.) opportunities to participate in this decision-making are always in the disadvantaged position. There are even those who might not participate in the decision-making process about those rights for principled reasons. The idea that human rights should ensure equal participation and should oppose domination, which is so important for Forst, requires that it is not factual agreement that decides the content of those rights within a dignity-based order. Secondly, effective forms of co-authorship in decisions about the normative order have thus far not been possible on a global scale, and this is perhaps even impossible for principled reasons. However, the entire idea of human rights is a universalistic one. Specific societies can, however, give themselves a normative order that fundamentally ignores the rights of human beings outside of this order - it is evident that this is not only a theoretical possibility. Thirdly, it is possible that people might de facto agree on a normative order in which they give up fundamentally important rights, central freedoms, legal security or the like, rights which are necessary for their exercise of their autonomy. I fail to see why this should be acceptable within a dignity-based normative order, simply because the people gave themselves this order.

So, whilst I agree with Forst that a normative order on the basis of human dignity is obliged to safeguard the citizens' opportunities to decide for themselves about rights and duties that should govern the normative order, this does not imply that there are no criteria by which to determine the content of those rights and duties. 
A further question concerns the scope of the right-holders. Forst writes:

'A moral argument and ascription is not a naturalistic or empiricist one; thus the justificatory theory does not require a kind of "justification driver's licence" as a precondition for the right to justification. Human beings who are not yet, or are no longer, in possession of their rational powers of justification are equally to be respected as justificatory equals, so that one ought to treat them on the basis of reasons that are justifiable to them given our best accounts of their justifiable interests and needs. ${ }^{17}$

I understand and agree that the ascription of a moral status to persons is not a 'naturalistic or empiricist' argument. Personhood is not a natural property, and there cannot and should not be political institutions which have the right to determine whether or not human beings have such a property to a degree sufficient for political participation. But this does not necessarily mean that the respect for autonomous persons coincides with equal respect for all members of the human species. Why should we see people in coma, future generations, or foetuses as being within the scope of those that are entitled to have co-authorship of the normative order? Of course, we can take their interests into account via a proxy, but why should we do so? And if we do not, do we fail to respect someone's right to justification? To avoid misunderstanding, I do not claim that we should restrict the respect for human dignity to those that are capable of articulating their interests themselves. But I think there is an argument necessary, which I have not yet seen within Forst's framework. Even if the ascription of a moral status is not a naturalistic one, this does not mean that there is no need to determine to whom we owe respect in the natural world; the scope could include all human beings from conception, nidation or birth onwards, including the braindead or heart-dead. I do not want to take a stance here, but there is a need to justify whatever position we defend. The answer cannot be that the citizens who determine their rights and duties themselves should freely decide this, because it is precisely the question of who falls within the scope of those that have a right to justification. Answers to this question do not have to fall into a naturalistic trap. If we understand the dignity of the human person as the normative reason to ascribe a moral status (with all the implications for the political order), the ascription of this status is not based on a biological property, but nonetheless we can ask whether it is rationally possible to ascribe the status of person we must respect to a foetus or a comatose patient. ${ }^{18}$

\section{Concluding remarks}

Rainer Forst's proposal of a Kantian approach on the basis of human dignity is from my point of view a real progress in the Frankfurt discourse. I see the advan-

17 Forst, 'The Justification of Basic Rights', 17.

18 Concerning my own position in this question, see Marcus Düwell, Bioethics: Methods, Theories, Domains (Oxford: Routledge, 2013), 109-24. 
tages of his proposal and acclaim his attempt to overcome certain problems in Habermas's concept, which he analyzes accurately, from my point of view. I furthermore fully understand his idea that such a Kantian approach is compatible with the view that human rights are the results of political power struggles. We need reasons to judge that human rights are not just one outcome of power struggles, but in a qualified sense a progress, something which it is worthwhile to defend, and the Kantian argument provides us with such a reason. I also agree that this moral justification will give us on the one hand reasons as to why we should organize the political-legal sphere in a specific way and urges us at the same time to respect the self-determination of the citizens. But - so far - I do not see how the transcendental argument works and why the determination of the rights and duties, and the scope of right-holders can and should be entirely a question of the political discourse. Kantian philosophy has more to say about this. In any case, I see this approach as a welcome and much needed opening for new discussions on human dignity. 